\begin{tabular}{c} 
Tersedia online di: http://ejournal-balitbang.kkp.go.id/index.php/bawal \\
e-mail:bawal.puslitbangkan@ gmail.com \\
BAWAL WIDYA RISET PERIKANAN TANGKAP \\
Volume 10 Nomor 3 Desember 2018 \\
p-ISSN: 1907-8226 \\
e-ISSN: 2502-6410 \\
BAWAL \\
Nomor Akreditasi Kementerian RISTEKDIKTI: 21/E/KPT/2018 \\
\hline \hline
\end{tabular}

\title{
POLA PERTUMBUHAN DAN FAKTOR KONDISI TONGKOL KOMO, Euthynnus affinis (Cantor, 1849) DI PERAIRAN TANJUNG LUAR NUSA TENGGARA BARAT
}

\section{GROWTH PATTERN AND CONDITION FACTOR OF KAWAKAWA, Euthynnus affinis (Cantor 1849) IN TANJUNG LUAR WATERS WEST NUSA TENGGARA}

\author{
Maya Agustina $^{* 1}$, Irwan Jatmiko ${ }^{1}$ dan Ririk Kartika Sulistyaningsih ${ }^{1}$ \\ ${ }^{1}$ Loka Riset Perikanan Tuna, Jl. Mertasari No.140, Sidakarya, Kota Denpasar, Bali-80224, Indonesia \\ Teregistrasi I tanggal: 14 Desember 2017; Diterima setelah perbaikan tanggal: 07 Agustus 2018; \\ Disetujui terbit tanggal: 28 September 2018
}

\begin{abstract}
ABSTRAK
Tongkol komo (Euthynnus affinis Cantor, 1849) merupakan salah satu hasil tangkapan yang cukup penting bagi perikanan skala kecil di Tanjung Luar, Nusa Tenggara Barat. Spesies ini masuk ke dalam kelompok tuna neritik yang sebagian besar diusahakan dengan menggunakan alat tangkap purse seine dan gillnet. Penelitian ini bertujuan untuk mengetahui pola pertumbuhan dan faktor kondisi tongkol komo. Pengumpulan data dilakukan selama 12 bulan dari Januari - Desember 2016 di PPI Tanjung Luar, Nusa Tenggara Barat. Pengambilan data bulanan secara berkesinambungan dilakukan dengan bantuan tenaga enumerator. Data sebanyak 1.297 spesimen komo telah diukur panjang cagak $(\mathrm{cmFL})$ dan ditimbang beratnya $(\mathrm{kg})$. Hasil pengukuran menunjukkan sebaran panjang berkisar antara $24-71 \mathrm{cmFL}$, dengan rata-rata 51,66 cmFL dan berat 0,21-7,05 kg, dengan rata-rata $2,72 \mathrm{~kg}$. Analisis hubungan panjang berat diperoleh hasil $W=0,00001 F L^{3,114}$ dengan koefisien determinasi $\left(R^{2}\right)$ 0,978 . Pola pertumbuhan bersifat alometrik positif $(b>3)$ menunjukkan bahwa pertambahan berat lebih cepat daripada pertambahan panjangnya. Faktor kondisi relatif $(K n)$ tertinggi terjadi pada batas atas kelas panjang 45 $\mathrm{cm}$ sebesar 1,187 dan terendah terjadi pada batas atas kelas panjang $30 \mathrm{~cm}$ sebesar 0,940. Faktor kondisi relatif bulanan cenderung stabil dengan nilai tertinggi terjadi pada bulan November sebesar 1,140 dan terendah pada bulan Maret sebesar 1,033 dan cenderung berfluktuasi pada ikan-ikan berukuran kecil, sedangkan pada ikan berukuran dewasa menunjukkan tren yang menurun seiring dengan bertambahnya ukuran panjang.
\end{abstract}

Kata Kunci: Pola pertumbuhan; faktor kondisi; tongkol komo; Tanjung Luar

\section{ABSTRACT}

Kawakawa (Euthynnus affinis Cantor, 1849) one of the important catch for small-scale fisheries in Tanjung Luar, West Nusa Tenggara. This species is included in neritic tuna group that mostly utilized by using purse seine and gillnet. The objectives of this research are to investigate the growth pattern and condition factor of this particular species. Data collection was conducted for 12 months from January to December 2016 in Tanjung Luar Port, West Nusa Tenggara. Data were collected in twelve consecutive months by enumerators. Total of 1,297 specimens were collected, measured ( $\mathrm{cmFL}$ ) and weighted $(\mathrm{kg})$. The measurements showed that the length of ranged from $24-71 \mathrm{cmFL}$ with average of $51.66 \mathrm{cmFL}$. The weight ranged from 0.21-7.05 $\mathrm{kg}$ with average of $2.72 \mathrm{~kg}$. Analysis of length-weight relationships was $W=0.00001 \mathrm{FL}^{3.114}$ with determination coefficient $\left(R^{2}\right)$ 0.978 . Growth pattern of positive allometric $(b>3)$ where the additional of weight proceeded faster than the of length increments. The highest relative condition factor (Kn) occurred at upper limit of length class $45 \mathrm{~cm}$ with 1.187 and the lowest at $30 \mathrm{cmFL}$ with 0.940. Monthly relative condition factor tends to stable with the highest value occurred on November with 1.140 and the lowest on March with 1.033 and tend to fluctuated for small size group. While for adult fish tend to decrease along with the length increase.

Keywords: Growth pattern; condition factor; Kawa-kawa; Tanjung Luar 


\section{PENDAHULUAN}

Tuna neritik merupakan kelompok tuna yang dominan tertangkap di perikanan pantai dan tergolong dalam perikanan tuna skala kecil (small scale) (Naderi, 2016). Di Indonesia terdapat 4 (empat) jenis tongkol (neritic tuna) yang dikelola dalam Rencana Pengelolaan Perikanan (RPP) TCT yaitu terdiri dari lisong (Auxis rochei), tongkol krai (Auxis thazard), tongkol komo (Euthynnus affinis) dan tongkol abu-abu (Thunnus tonggol) (KKP, 2015). Tongkol komo atau dikenal dengan nama kawakawa merupakan jenis ikan pelagis dan perenang cepat yang hidup bergerombol dimana daerah penyebarannya berada di perairan pantai dan oseanik (Blackburn, 1965 dalam Nurhayati, 2001). Tongkol komo (Euthynnus affinis) merupakan salah satu komoditas yang mewakili tuna neritik sebanyak $10 \%$ dalam perdagangan perikanan laut (seafood) dunia (Ahmed et al., 2015). Di Indonesia tongkol komo adalah komoditas yang mempunyai nilai ekonomis penting karena merupakan sumber mata pencaharian nelayan dan salah satu sumber devisa Negara (Wagiyo et al., 2018).

Sebaran tongkol komo di Indonesia terdapat di perairan dangkal atau bersifat neritik (Wagiyo et al., 2018). Salah satu pendaratan tongkol komo di WPP 573 adalah di Pangkalan Pendaratan Ikan (PPI) Tanjung Luar, Nusa Tenggara Barat. Nelayan di daerah ini menangkap tongkol komo dengan menggunakan pukat cincin, rawai hanyut dan tonda parabola. Menurut Suwarso (2009), tongkol komo yang didaratkan dari Samudera Hindia sebesar $33 \%$ diantaranya berasal dari alat tangkap gillnet dan $67 \%$ lainnya dari purse seine. Selanjutnya Wijopriono \& Rachmawati (2015) menyatakan di Palabuhanratu, tongkol ditangkap menggunakan payang, alat tangkap yang termasuk kategori jaring lingkar, di samping jaring insang, pancing tonda, bagan dan pukat cincin.

Dalam biologi perikanan, hubungan panjang berat ikan merupakan salah satu informasi pelengkap yang harus diketahui dalam kaitan pengelolaan sumber daya perikanan (Vanichkul \& Hongskul dalam Merta, 1993). Lebih lanjut (Richter, 2007; \& Blackweel et al. (2000) menyebutkan bahwa pengukuran panjang berat ikan bertujuan untuk mengetahui variasi berat dan panjang dari ikan secara individual atau kelompok sebagai suatu petunjuk tentang kegemukan, kesehatan, produktifitas dan kondisi fisiologis termasuk perkembangan gonad. Analisa hubungan panjang berat juga dapat mengestimasi faktor kondisi atau sering disebut dengan index of plumpness, yang merupakan salah satu hal penting dari pertumbuhan untuk membandingkan kondisi atau keadaan kesehatan relatif populasi ikan atau individu tertentu (Everhart \& Youngs, 1981).
Produksi tongkol komo pada 2010 sebesar 390.595 ton, terus mengalami peningkatan rata-rata per tahun 7,27 \%, menjadi 520.460 ton pada 2015 (KKP, 2015). Permintaan terhadap ikan tongkol yang terus meningkat berbanding lurus dengan tingginya upaya penangkapan sehingga dapat memberikan tekanan terhadap keberlanjutan stok sumberdaya ikan tersebut (Fayetri et al., 2013). Menurut IOTC (2016) kondisi stok tongkol komo di Samudera Hindia dalam keadaan baik (not overfished and not subject to overfishing) dengan $\mathrm{F}_{2013} / \mathrm{F}_{\text {MSY } 2013}$ sebesar 0.98 atau sebesar $98 \%$ dari total MSY Maximum Sustainable Yield. Dalam jangka panjang, kondisi ini dapat memburuk jika sumber daya ini tidak dikelola dengan baik. Meningkatnya permintaan produk tongkol di dunia dalam beberapa tahun terakhir sangat berdampak terhadap berkembangnya armada secara berlebih (overcapacity) sehingga diperlukan penelitian yang menggambarkan kondisi stok ikan tuna neritik sebagai dasar dalam pengelolaan dan pengambilan keputusan. Penelitian ini bertujuan untuk mengestimasi pola pertumbuhan dan faktor kondisi tongkol komo yang tertangkap di Samudera Hindia bagian timur. Informasi ini sangat diperlukan sebagai bahan dasar pengelolaan ikan tongkol sehingga dapat dimanfaatkan secara berkelanjutan.

\section{BAHANDANMETODE}

Pengumpulan data dilakukan dari Januari - Desember 2016 di PPI Tanjung Luar, Nusa Tenggara Barat dengan bantuan tenaga enumerator. Pengukuran panjang dilakukan menggunakan kaliper dengan ketelitian $1 \mathrm{~cm}$ dan berat menggunakan timbangan dengan ketelitian $1 \mathrm{~g}$. Data yang dikumpulkan kemudian dianalisis untuk mengetahui sebaran panjang dan hubungan panjang beratnya.

Untuk mengetahui hubungan panjang-berat ikan digunakan rumus Effendie (2002):

$W=a L^{b}$

dimana;

$W=$ berat ikan $(\mathrm{kg})$

$L=$ panjang cagak ikan $(\mathrm{cm})$

$a$ = intercept (perpotongan antara garis regresi dengan sumbu y)

$b=$ koefisien regresi (sudut kemiringan garis)

Dari persamaan tersebut dapat diketahui pola pertumbuhan ikan yang diamati. Nilai b yang diperoleh digunakan untuk menentukan pola pertumbuhan dengan kriteria:

a. Jika $b=3$, pertumbuhan bersifat isometrik, yaitu pertambahan panjang sama dengan pertambahan berat, 
b. Jika $b>3$, maka pola pertumbuhan bersifat allometrik positif, yaitu pertambahan berat lebih cepat daripada pertambahan panjangnya,

c. Jika $b<3$, maka pola pertumbuhan bersifat allometrik negatif, yaitu pertambahan panjang lebih cepat daripada pertambahan berat.

Untuk mengetahui apakah nilai b yang diperoleh lebih besar, sama dengan atau lebih kecil dari 3 digunakan uji t pada selang kepercayaan 95\% (Steel \& Torrie, 1993).

Sedangkan analisis faktor kondisi dilakukan pada setiap kisaran panjang dan setiap bulan. Faktor kondisi dihitung dengan membandingkan berat rata-rata ikan dengan berat prediksi yang diperoleh dari parameter penghitungan panjang berat secara umum. Metode yang digunakan untuk penghitungan faktor kondisi relatif menggunakan rumus King (2007):

$K_{n}=\frac{W_{m}}{W_{p}}$

dimana;

$K_{n}=$ kondisi faktor relatif

$W_{m}=$ rata-rata berat
$W_{p}=$ berat prediksi dari berat ikan dengan ukuran yang sama

\section{HASIL DAN BAHASAN Hasil}

Tercatat sebanyak 1.297 ekor ikan tongkol komo yang diukur panjang cagak $(\mathrm{cm})$ dan ditimbang beratnya $(\mathrm{kg})$. Hasil pengukuran menunjukkan bahwa tongkol komo mempunyai sebaran panjang antara $24-71 \mathrm{cmFL}$ dengan rata-rata $51,66 \mathrm{cmFL}$ dan berat $0,21-7,05 \mathrm{~kg}$ dengan ratarata $2,72 \mathrm{~kg}$ (Tabel 1). Analisis hubungan panjang berat diperoleh hasil $W=0,00001 F L^{3,114}$ dengan koefisien determinasi $\left(R^{2}\right) 0,978$, menunjukkan bahwa panjang cagak dapat mengestimasi berat tongkol komo dengan tingkat keakuratan sebesar 97,8\% (Gambar 1). Hasil uji- $t$ nilai $b$ setiap bulan menunjukkan bahwa pola pertumbuhan tongkol komo didominasi oleh sifat isometrik (terjadi dalam 7 bulan), diikuti oleh alometrik positif ( 4 bulan) dan hanya satu kali bersifat alometrik negatif yang hanya terjadi pada bulan Agustus. Pola pertumbuhan tongkol komo secara total (penggabungan data) bersifat alometrik positif $(b>3)$, menunjukkan bahwa pertambahan berat tongkol komo lebih cepat daripada pertambahan panjangnya (Tabel 1).

Tabel 1. Parameter dan pola pertumbuhan tongkol komo yang didaratkan di PPI Tanjung Luar.

Table 1. Parameter and growth pattern of kawakawa landed in Tanjung Luar Fishing Port.

\begin{tabular}{|c|c|c|c|c|c|c|c|c|c|c|c|c|c|c|c|c|}
\hline \multirow{2}{*}{ Bulan } & \multirow{2}{*}{$\mathrm{N}$} & \multicolumn{5}{|c|}{ Panjang Cagak (cm) } & \multicolumn{6}{|c|}{ Berat (kg) } & \multicolumn{3}{|c|}{ Parameter } & \multirow{2}{*}{ Pola Pertumbuhan } \\
\hline & & $\min -$ & $\max$ & rata-rata & \pm & $S E$ & $\min$ & - & $\max$ & rata-rata & \pm & $S E$ & $\mathrm{a}$ & $\mathrm{b}$ & $\mathrm{R}^{\wedge} 2$ & \\
\hline Jan & 85 & $35,0-$ & 65,0 & 53,84 & \pm & 0,77 & 0,50 & - & 4,70 & 2,97 & \pm & 0,11 & 0,000002 & 3,561 & 0,961 & alometrik positif \\
\hline Feb & 41 & $36,0-$ & 65,0 & 52,41 & \pm & 1,19 & 0,50 & - & 4,60 & 2,72 & \pm & 0,17 & 0,000002 & 3,551 & 0,956 & alometrik positif \\
\hline Mar & 67 & $24,0=$ & 66,0 & 44,48 & \pm & 1,58 & 0,21 & - & 4,72 & 1,96 & \pm & 0,18 & 0,000004 & 3,405 & 0,991 & alometrik positif \\
\hline Apr & 136 & $40,0-$ & 69,0 & 53,17 & \pm & 0,63 & 1,13 & - & 5,57 & 2,86 & \pm & 0,09 & 0,000023 & 2,944 & 0,977 & isometrik \\
\hline Mei & 147 & $24,0=$ & 69,0 & 48,23 & \pm & 1,06 & 0,24 & $=$ & 5,53 & 2,45 & \pm & 0,12 & 0,000011 & 3,117 & 0,990 & alometrik positif \\
\hline Jun & 118 & $33,6=$ & 71,0 & 52,30 & \pm & 0,86 & 0,69 & - & 7,05 & 2,85 & \pm & 0,13 & 0,000014 & 3,058 & 0,985 & isometrik \\
\hline Jul & 98 & $35,0-$ & 67,0 & 53,77 & \pm & 0,67 & 0,66 & - & 5,13 & 2,82 & \pm & 0,10 & 0,000021 & 2,948 & 0,924 & isometrik \\
\hline Agu & 238 & $32,0=$ & 71,0 & 52,61 & \pm & 0,48 & 0,66 & $=$ & 5,54 & 2,70 & \pm & 0,07 & 0,000024 & 2,917 & 0,962 & alometrik negatif \\
\hline Sep & 232 & $24,0-$ & 71,0 & 51,80 & \pm & 0,73 & 0,25 & - & 6,55 & 2,84 & \pm & 0,09 & 0,000014 & 3,065 & 0,983 & isometrik \\
\hline Okt & 38 & $37,0-$ & 70,0 & 57,11 & \pm & 1,20 & 0,83 & - & 5,78 & 3,50 & \pm & 0,18 & 0,000031 & 2,870 & 0,975 & isometrik \\
\hline Nov & 46 & $31,8=$ & 69,0 & 50,48 & \pm & 1,73 & 0,58 & - & 5,03 & 2,71 & \pm & 0,22 & 0,000016 & 3,034 & 0,979 & isometrik \\
\hline Des & 51 & $32,0-$ & 64,0 & 49,04 & \pm & 1,24 & 0,57 & - & 4,13 & 2,22 & & 0,15 & 0,000027 & 2,884 & 0,976 & isometrik \\
\hline Total & 1297 & $24,0-$ & 71,0 & 51,66 & \pm & 1,01 & 0,21 & - & 7,05 & 2,72 & \pm & 0,13 & 0,000011 & 3,114 & 0,978 & alometrik positif \\
\hline
\end{tabular}

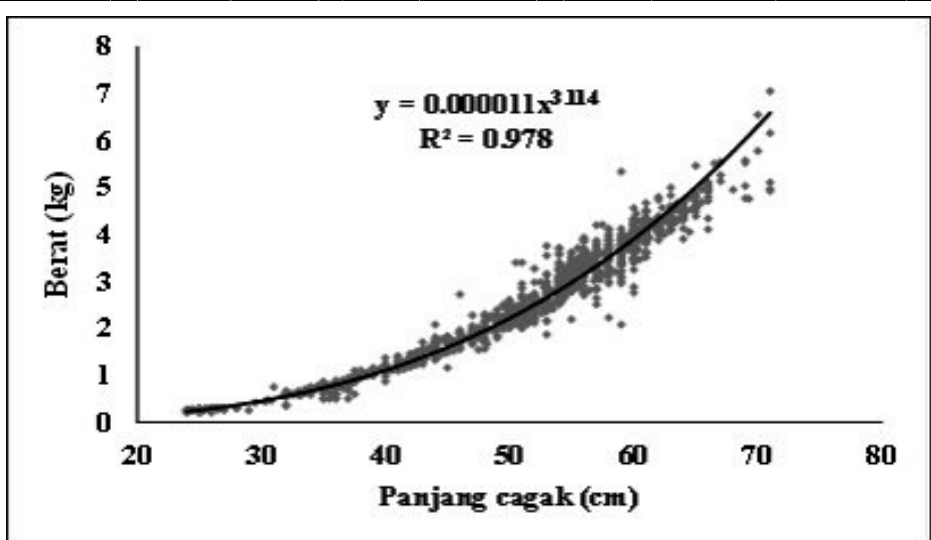

Gambar 1. Hubungan panjang berat tongkol komo yang didaratkan di PPI Tanjung Luar.

Figure 1. Length-weight relationship of kawakawa landed in Tanjung Luar Fishing Port. 
Faktor kondisi relatif $(K n)$ tongkol komo adalah 1,101 dan cenderung berfluktuasi pada ikan-ikan berukuran kecil, sedangkan pada ikan yang dewasa menunjukkan tren yang menurun seiring dengan bertambahnya ukuran panjang. Faktor kondisi relatif tertinggi terjadi pada batas atas kelas panjang $45 \mathrm{~cm}$ sebesar 1,187 dan terendah terjadi pada batas atas kelas panjang $30 \mathrm{~cm}$ sebesar 0,940 (Gambar 2). Faktor kondisi relatif bulanan cenderung stabil dengan nilai tertinggi terjadi pada bulan November sebesar 1,140 dan terendah pada bulan Maret sebesar 1,033 (Gambar 3).

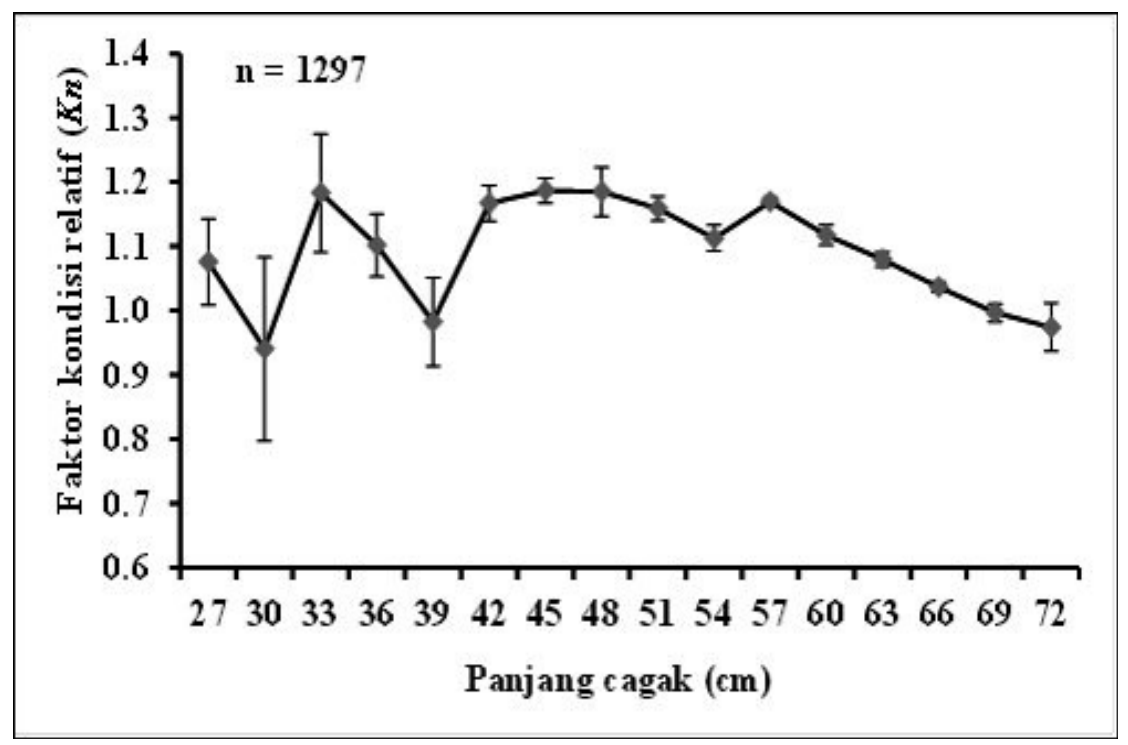

Gambar 2. Faktor kondisi relatif berdasarkan kisaran panjang tongkol komo yang didaratkan di PPI Tanjung Luar. Figure 2. Relative condition factor based on length frequency of kawakawa landed in Tanjung Luar Fishing Port.

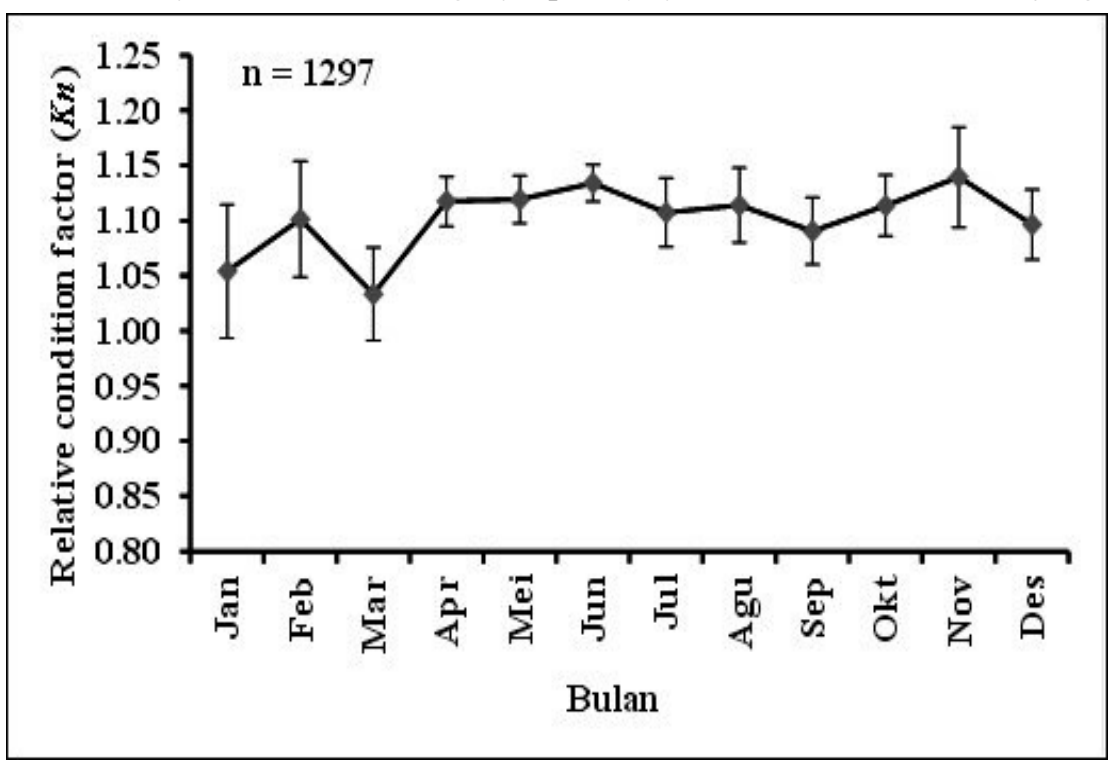

Gambar 3. Faktor kondisi relatif berdasarkan bulan tongkol komo yang didaratkan di PPI Tanjung Luar.

Figure 3. Relative condition factor based on month of kawakawa landed in Tanjung Luar Fishing Port.

\section{Bahasan}

Berdasarkan ukuran panjang ikan tongkol komo yang diperoleh dapat diketahui bahwa panjang ikan di perairan Tanjung Luar lebih besar bila dibandingkan dengan ukuran ikan di Laut Jawa. Penelitian Chodrijah et al. (2013) menyatakan panjang ikan tongkol komo di Laut Jawa berkisar antara 11,7-55,4 cm dengan rata-rata 34,1 cm. Menurut Kaymaran \& Darvishi (2012), panjang ikan tongkol komo di perairan Iran berkisar antara $28-88 \mathrm{~cm}$, dengan rata-rata $66 \mathrm{~cm}$ selanjutnya Kasim \& Abdussamad, (2003) dalam Kaymaram \& Daryishi (2012) menyebutkan bahwa $E$. affinis di perairan India mempunyai kisaran panjang yang lebih besar yaitu $18-83 \mathrm{~cm}$. Di Perairan Barat Sumatera, sebaran panjang berkisar antara 30-60 cm (Jatmiko et al., 2014). Di Perairan Malaka, Wagiyo et al., (2018) menuliskan panjang ikan tongkol komo pada kisaran 16-60 cmFL dengan nilai rata-rata $38 \mathrm{cmFL}$ dan berat pada kisaran 93-2.577gr atau nilai rata-rata 957 gr. Perbedaan kisaran panjang ikan dapat disebabkan oleh kondisi 
lingkungan perairannya. Motlagh et al., (2010) dalam Kaymaram \& Daryishi (2012) menyebutkan perbedaan alat tangkap yang digunakan dan kondisi perairan dapat mengakibatkan perbedaan kisaran panjang ikan. Sedangkan menurut Suruwaky \& Gunaisah (2013), panjang berat ikan yang tertangkap dapat dipengaruhi oleh eksploitasi ikan secara berlebihan. Semakin banyak tertangkap maka akan semakin kecil ukuran ikan.

Pola pertumbuhan dapat ditentukan berdasarkan nilai $b$ yang diperoleh dari persamaan hubungan panjang berat (Manik, 2009). Analisis hubungan panjang berat diperoleh hasil $\mathrm{W}=0,00001 \mathrm{FL}^{3,114}$ dengan koefisien determinasi $\left(R^{2}\right)$ 0,978 dan diketahui pola pertumbuhan tongkol komo bersifat allometrik positif yaitu pertambahan bobot lebih cepat daripada pertambahan panjangnya. Hal ini sama dengan penelitian Wagiyo et al. (2018) tongkol komo yang tertangkap di perairan Malaka mempunyai nilai hubungan panjang berat $R^{2}=0,946$ dan nilai $b=3,2402$ bersifat allometrik positif. Akan tetapi hal ini berbeda dengan hasil penelitian Fayetri et al. (2013) menyatakan bahwa pola pertumbuhan tongkol komo di Kepulauan Natuna bersifat isometrik yang berarti pertambahan panjang ikan sama dengan pertambahan beratnya. Hasil penelitian ini serupa dengan penelitian Chodrijah et al. (2013) dan Masuswo \& Widodo (2016) yang menyebutkan pola pertumbuhan tongkol komo di laut jawa bersifat isometrik dengan persamaan $\mathrm{W}=0,0636 \mathrm{~L} 2,6497\left(\mathrm{r}^{2}=0,8409\right)$. Menurut Dwirastina \& Makri (2013), perbedaan pola pertumbuhan pada ikan dapat disebabkan oleh tiga faktor yaitu umur, jenis ikan dan kondisi lingkungannya.

Perbedaan laju pertumbuhan dapat dipengaruhi oleh faktor internal serta eksternal (Breet, 1979; Kamler, 1992; Wootton, 1998 dalam Schluderman et al., 2009). Csirke (1980) dalam Hartaty et al., (2014), lebih lanjut menyatakan bahwa faktor lingkungan mempengaruhi perbedaan nilai pertumbuhan dari spesies ikan yang sama pada lokasi yang berbeda. Faktor lingkungan tersebut seperti ketersediaan makanan, suhu perairan, oksigen terlarut, ukuran ikan dan kematangan gonad. Selain itu kondisi lingkungan yang berubah juga dapat mengakibatkan kondisi ikan berubah sehingga hubungan panjang bobot akan menyimpang dari hukum kubik (Merta, 1993). King (2007) menyatakan bahwa hubungan panjang bobot ikan dapat digunakan untuk menentukan kemungkinan perbedaan antara jenis yang sama pada stok yang berbeda. Kegunaan lain dari analisa hubungan panjang bobot yaitu dapat digunakan untuk melakukan estimasi faktor kondisi atau sering disebut dengan index of plumpness, yang merupakan salah satu derivate penting dari pertumbuhan untuk membandingkan kondisi atau keadaan kesehatan relatif populasi ikan atau individu tertentu (Everhart \& Youngs, 1981).
Berdasarkan hasil pengamatan, faktor kondisi relatif ikan tongkol komo cenderung berfluktuasi pada ikan-ikan berukuran kecil. Hal ini diduga karena jumlah sampel pada ikan ukuran kecil sangat sedikit yang ditunjukkan dengan galat baku (standard error) yang cukup tinggi. Sedangkan pada ikan yang dewasa menunjukkan tren yang menurun seiring dengan bertambahnya ukuran panjang. Faktor kondisi relatif tongkol komo menunjukkan nilai yang tinggi terjadi pada kisaran panjang $45-51 \mathrm{~cm}$. Hal ini berkaitan dengan fase reproduksi tongkol komo yang mengalami pertama kali matang gonad pada ukuran $47-51 \mathrm{~cm}$ (Johnson \& Tamatamah, 2013) sehingga menambah berat tubuh ikan (faktor kemontokan). Sedangkan faktor kondisi relatif bulanan cenderung stabil sepanjang tahun. Hal ini disinyalir bahwa tongkol komo di perairan Selatan Jawa hidup di lingkungan perairan dan sumber makanan yang relatif sama. Selain itu, nilai faktor kondisi juga dapat dipengaruhi oleh kepadatan populasi, tingkat kematangan gonad, makanan, jenis kelamin, dan umur ikan (Effendie, 2002). Faktor kondisi dapat menunjukkan keadaan baik atau tidaknya panjang berat ikan yang dinyatakan dalam angka dan dilihat dari segi kapasitas fisik untuk survival dan reproduksi (Effendie, 1997). Faktor kondisi ikan tongkol komo di Perairan Tanjung Luar mengindikasikan dalam kondisi yang baik dan dapat dikonsumsi dengan nilai 1,033 - 1,140 setiap bulannya. Menurut Wujdi et al. (2012), Nilai faktor kondisi yang lebih dari satu juga mengindikasikan bahwa contoh ikan yang diamati berada dalam kondisi lingkungan yang baik dan dapat digunakan untuk konsumsi.

\section{KESIMPULAN}

Pola pertumbuhan tongkol komo (Euthynnus affinis) bersifat allometrik positif yang berarti pertambahan berat lebih cepat daripada pertambahan panjangnya. Faktor kondisi relatif tongkol komo cenderung berfluktuasi pada ikan-ikan berukuran kecil, sedangkan pada ikan yang dewasa menunjukkan tren yang menurun seiring dengan bertambahnya ukuran panjang Faktor kondisi relatif bulanan cenderung stabil dengan nilai tertinggi terjadi pada bulan November sebesar 1,140 dan terendah pada bulan Maret sebesar 1,033.

\section{PERSANTUNAN}

Penelitian ini dibiayai dari DIPA kegiatan riset Loka Riset Perikanan Tuna (LRPT) tahun 2016. Peneliti mengucapkan terima kasih kepada Sdr. Galih Rakasiwi sebagai enumerator di PPI Tanjung Luar yang telah membantu dalam proses pengumpulan data penelitian ini, Abram Barata sebagai koordinator kegiatan enumerasi di PPI Tanjung Luar dan Rusjas Mashar sebagai verifikator kegiatan enumerasi di PPI Tanjung Luar 


\section{DAFTAR PUSTAKA}

Ahmed, Q., Yousuf, F., Sarfraz, M., Alia, Q. M., Balkhourd, M., Safie, S. Z., \& Ashraff, M.A. (2015). Euthynnus affinis (little tuna): fishery, bionomics, seasonal elemental variations, health risk assessment and conservational management. Frontiers in Life Science, 8(1), 71-96.

Blackweel, B.G., Brown, M.L., \& Willis, D.W. (2000). Relative weight $(\mathrm{Wr})$ status and current use in fisheries assessment and management. Reviews in fisheries Science, 8, 1-44.

Chodrijah, U., Hidayat, T., \& Noegroho, T. (2013). Estimasi parameter populasi ikan tongkol komo (Euthynnus affinis) di perairan Laut Jawa. BAWAL, 5(3), 167-174.

Dwirastina, M., \& Makri. (2013). Hubungan Panjang Berat dan Faktor Kondisi Ikan Sepengkah (Parambassis Wolffi) di Sungai Rokan, Provinsi Riau. ISSN 1829 586x, 10. (2), $64-69$.

Effendie, I.M. (1997). Biologi perikanan. (p.163) Yayasan Pustaka Nusatama. Yogyakarta.

Effendie, I.M. (2002). Biologi perikanan. (163:59 p). Yayasan Pustaka Nusatama. Yogyakarta.

Everhart, W.H., \& Youngs, W. D. (1981). Principles of fishery Science (p. 349). 2nd Edition Comstock Publishing Associates, a division of Cornell University Press, London.

Fayetri, W.R., Efrizal, T., \& Zulfika,A. (2013). Kajian analitik stok ikan tongkol (Euthynnus affinis) berbasis data panjang berat yang di daratkan di tempat pendaratan ikan pasar Sedanau kabupaten Natuna. Diupload pada Jurnal Umrah.ac.id. http:jurnal.umrah.ac.id/wp-content/uploads/2013/08/WAN-RITA-FAYETRI09025424071.pdf

Hartaty, H. Amalia, A.C., \& Mashar, R. (2014). Estimasi parameter populasi tongkol balaki (Auxiz thazard thazard) di Perairan Samudera Hindia Barat Sumatera. Seminar Hasil Penelitian Terbaik tahun 2014, 183189.

Indian Ocean Tuna Commission (IOTC). (2016). Report of the 6th Session of the IOTC working party on neritic tunas. Mahé, Seychelles, 21-24 June 2016. p. 89.

Jatmiko, I., Sulistyaningsih., \& Nugroho, D. (2014). Laju pertumbuhan, laju kematian dan eksploitasi tongkol komo, Euthynnus affinis (Cantor 1849), di perairan Samudra Hindia Barat Sumatera. BAWAL, 6(2), 69-76.
Johnson, M.G. \& A.R. Tamatamah. (2013). Length frequency distribution, mortality rate and reproductive biology of kawakawa (Euthynnus affinis-Cantor, 1849) in the Coastal Waters of Tanzania. Pakistan Journal of Biological Sciences, 16(21), 1270-1278.

Kaymaran, F. \& Darvishi, M. (2012). Growth and mortality parameters of Euthynnus affinis in the northern part of the Persian Gulf and Oman Sea. Second Working Party on Neritic Tunas, Malaysia, 19-21 November 2012 IOTC-2012-WPNT02-14 Rev_1. 14 p.

Keputusan Kementerian Kelautan dan Perikanan (KKP). (2015). Keputusan Menteri Kelautan dan Perikanan No.107 Tahun 2015 tentang Rencana Pengelolaan Perikanan Tuna Cakalang Tongkol.

King, M. (2007). Fisheries biology, Assessment and Management. Second edition. Blackwell Sciencetific Publication. Oxford. $381 \mathrm{p}$.

Manik, N. (2009). Hubungan panjang-berat dan faktor kondisi ikan layang (Decapterus russelli) dari perairan Sekitar Teluk Likupang Sulawesi Utara. Oseanologi dan Limnologi di Indonesia, 35(1), 65 - 74.

Masuswo, R., \& Widodo, A. A. (2016). Karakteristik biologi ikan tongkol komo (Euthynnus affinis) yang tertangkap jaring insang hanyut di Laut Jawa. BAWAL, 8(1), 57-63.

Merta, I.G.S. (1993). Hubungan panjang, berat badan, dan faktor kondisi ikan lemuru, Sardinella lemuru Bleeker, 1853 dari perairan selat Bali. Jurnal Penelitian Perikanan Laut, (73), 35-44.

Naderi, R. A. (2016). Assessment of social consideration on Neritic tuna in Iran fishery management. Working party on Neritic Tuna (WPNT06), IOTC-2016WPNT06-12 Rev_1.

Nurhayati, M. (2001). Analisis beberapa aspek potensi ikan tongkol (Euthynnus affinis) di perairan Pelabuhan Ratu. Skripsi. Program Studi Ilmu Kelautan. Fakultas Perikanan dan Ilmu Kelautan, IPB. Bogor. p. 66.

Richter, T.J. (2007). Development and evaluation of standard weight equations for bridgelip sucker and largescale sucker. North American Journal of Fisheries Management, 27, 936-939.

Schluderman, E. Keckeis, H., \& Nemeschkal, L. (2009). Effect of initial size on daily growth and survival in freshwater Chondrostoma nasus larvae: a field survey. Journal of Fish Biology, 74, 939-955. 
Steel, R. G. D., \& Torrie, J. H. (1993). Prinsip dan prosedur statistika (Pendekatan Biometrik) Penerjemah $B$. Sumantri. (p. 772). Gramedia Pustaka Utama, Jakarta.

Suruwaky, A.M., \& Gunaisah, E. (2013). Identifikasi tingkat eksploitasi sumber daya kembung lelaki (Rastrelliger kanagurta) di tinjau dari hubungan panjang berat. Jurnal Akuatika, IV(2).

Suwarso. (2009). Variasi musiman hasil tangkapan ikan tongkol (Euthynnus sp.; Fam. Scombridae) di Laut Jawa. Prosiding Seminar Nasional Tahunan VI Hasil Penelitian Perikanan dan Kelautan.Universitas Gadjah Mada. 25 Juli 2009 Yogyakarta. p. 6.
Wagiyo, K. Pane A. R .P., \& Chodrijah, U. (2018). Parameter populasi, aspek biologi dan penangkapan tongkol komo (Euthynnus Affinis Cantor, 1849) di Selat Malaka. J.Lit.Perikan.Ind, 23(4), 287-297.

Wijopriono \& Rachmawati, P.F. (2015). Perikanan tongkol dan daya dukungnya terhadap penyediaan bahan baku industri pengolahan di Palabuhanratu. J. Lit. Perikan. Ind, 21(1), 17-24.

Wujdi, A., Suwarso., \& Wudianto. (2012). Hubungan panjangbobot, faktor kondisi dan struktur ukuran ikan lemuru (Sardinella Lemuru Bleeker, 1853) di Perairan Selat Bali. BAWAL, 4(2), 83-89. 